\title{
Insights into the present and future of cartilage regeneration and joint repair
}

\author{
H. Evenbratt ${ }^{1 *} \mathbb{C}$, L. Andreasson ${ }^{1,2}$, V. Bicknell ${ }^{1}$, M. Brittberg ${ }^{3}$, R. Mobini $^{1}$ and S. Simonsson ${ }^{2}$
}

\begin{abstract}
Knee osteoarthritis is the most common joint disease. It causes pain and suffering for affected patients and is the source of major economic costs for healthcare systems. Despite ongoing research, there is a lack of knowledge regarding disease mechanisms, biomarkers, and possible cures. Current treatments do not fulfill patients' long-term needs, and it often requires invasive surgical procedures with subsequent long periods of rehabilitation. Researchers and companies worldwide are working to find a suitable cell source to engineer or regenerate a functional and healthy articular cartilage tissue to implant in the damaged area. Potential cell sources to accomplish this goal include embryonic stem cells, mesenchymal stem cells, or induced pluripotent stem cells. The differentiation of stem cells into different tissue types is complex, and a suitable concentration range of specific growth factors is vital. The cellular microenvironment during early embryonic development provides crucial information regarding concentrations of signaling molecules and morphogen gradients as these are essential inducers for tissue development. Thus, morphogen gradients implemented in developmental protocols aimed to engineer functional cartilage tissue can potentially generate cells comparable to those within native cartilage. In this review, we have summarized the problems with current treatments, potential cell sources for cell therapy, reviewed the progress of new treatments within the regenerative cartilage field, and highlighted the importance of cell quality, characterization assays, and chemically defined protocols.
\end{abstract}

Key Words: Articular Cartilage, Osteoarthritis, Joint treatments, Stem cell therapy, Gradients, Differentiation, Chondrocyte characterization

\section{Background}

Osteoarthritis $(\mathrm{OA})$ is the most common form of chronic joint disease, affecting all joints in the body, resulting in progressive cartilage degeneration. Risk factors associated with OA include age, obesity, family history, or trauma that has caused damage to the cartilage (Haq et al., 2003). Physical inactivity has also been shown to lead to cartilage degradation as joints require mechanical load and motion to maintain healthy cartilage structure and function (Sophia Fox et al., 2009). As cartilage is an avascular tissue with sparse cell density, it has poor regenerative capacity. Due to this, OA results in pain,

\footnotetext{
*Correspondence: Hanne.evenbratt@clinescientific.com

${ }^{1}$ Cline Scientific AB, SE-431 53 Mölndal, Sweden

Full list of author information is available at the end of the article
}

dysfunction, and substantial healthcare costs (Hudetz et al., 2017; Hiligsmann \& Reginster, 2013). In addition to these direct effects, the disease leads to an indirect economic burden for societies due to decreased productivity and premature disability (Hiligsmann \& Reginster, 2013). Since age is a substantial risk factor (Haq et al., 2003), and that the global life expectancy continues to increase, OA-related costs will also increase with time. Therefore, the potential cost savings provided by a cure, or other better alleviation methods, will also be substantial given the high prevalence of people suffering from the disease worldwide.

Recent reviews discuss cell-based treatments of OA and cartilage defects with a different focus. Both Agarwal et al. and Wiggers et al. dive deep into clinical studies of cellular therapies for improved knee function and 
decreased pain (Agarwal et al., 2021; Wiggers et al., 2021). In their respective meta-analyses, Agarwal et al. show that such treatment may be effective, while Wiggers et al. concluded that there is limited evidence for a qualitative effect. The future of stem cell therapy is dependent on high-quality cartilage to repair damage to a greater extent than is possible today. Kamaraj et al. reviewed studies that used induced pluripotent stem cells (iPSCs) to produce high-quality cartilage and tested the effect in vivo (Kamaraj et al., 2021). They concluded that iPSCs offer a valuable source of cartilage for effective cellbased therapy and that comparability of study findings is of utmost importance, in line with the focus areas of this review. This review will present an overview of current and possible future strategies for cell-based treatments for OA and cartilage defects. It will address current progress within the regenerative medicine field. It will also address the need for robust protocols for generating stem cell-derived chondroprogenitors or chondrocytes and valid characterizations used in stem cell therapies.

\section{Cartilage}

Articular cartilage is a highly specialized and avascular tissue that is the most common type of cartilage covering the surface of articular joints (Schmutzer \& Aszodi, 2017). It consists primarily of water $(65-80 \%$ of wet weight), collagen fibers (10-20\% of wet weight and $60 \%$ of dry weight, where type II collagens represent $90-95 \%$ of the collagen fibers), and proteoglycans (10-15\% of wet weight). It also contains smaller amounts of other molecules such as glycoproteins, hyaluronan, and various elastic fibers, which form a dense extracellular matrix (ECM) network (Sophia Fox et al., 2009). The specialized cell type within adult cartilage, chondrocytes, is non-proliferating, and the cell density is relatively low. Only about $2 \%$ of cartilage consists of chondrocytes, where matrix proteins constitute the rest of the dry weight (Sophia Fox et al., 2009). The main function of chondrocytes is metabolic regulation, i.e., synthesis and degradation of ECM proteins, mainly collagen type II and aggrecan (Frazer et al., 1994). There are two alternative RNA splicing of collagen type II, one long-chained (collagen type IIA) characteristically expressed in pre-chondrocytes, and one short-chained (collagen type IIB) expressed in mature chondrocytes (Nah et al., 2001). Aggrecan is the most abundant proteoglycan within cartilage, and it is essential to maintain structure and function in this tissue. Due to its linkage to hyaluronan, aggrecan provides a hydrated gel structure necessary for biochemical and mechanical function. Aggrecan synthesis and degradation are regulated and, therefore, not constant throughout life. The degradation is directly linked to cartilage erosion and diseases such as OA (Song et al., 2007).

\section{Current treatments for $O A$}

Despite much ongoing research regarding OA, there is a lack of knowledge regarding disease-related biomarkers, disease mechanisms, and drug targets (Zhang et al., 2016). There is no existing drug-based disease-modifying therapy on the market, although potential drugs are currently under investigation. There is also no specific treatment for halting cartilage degradation (Fosang et al., 2003). Current treatments are patient-specific and depend on the levels of pain a patient experience. Treatments are focused on lifestyle modifications such as diet and physical activity, pain and inflammation-reducing drugs, interarticular drug treatments, cell transplantations, and if needed, entire joint replacements (Zhang et al., 2016). However, pain-relieving and anti-inflammatory medications do not prevent the progression of the disease. Since surgery is an invasive procedure followed by long rehabilitation periods, it is normally only recommended for patients with a severe pain history.

\section{Surgical methods}

Limb malalignment induces stress on articular cartilage, and when present in early OA, such malalignment causes further loss of articular cartilage. Unloading osteotomies can be used to realign the limb, reduce stress on degenerative cartilage, and to slow down disease progression. Osteotomies are used primarily for the knees, and can be used as a preservative tool for the joint (Mina et al., 2008). Joint distraction is a more recent technique where the bones are pulled apart to increase space, and the distracted area is fixed using pins combined with an external frame. It temporarily unloads the degenerative region, and the method has been used for OA conditions in the ankle and knee. Joint distraction appears to give patients short-term clinical and structural benefits with sustained effect up to 9 years (Goh et al., 2019).

Painful subchondral cysts in OA can be treated by subchondral plasty, filling the cysts with calcium phosphates and/or bone marrow concentrates (Szwedowski et al., 2020).

Joint replacements are a standard procedure with a limited lifespan that is used as late as possible in OA treatment. These procedures incur large costs for patients, hospitals, and healthcare systems. According to Chen et al., the money spent on joint replacements in the US alone has increased from ca 7 billion dollars in 1997 to over 22 billion dollars in 2004, with no sign of slowing down (Chen et al., 2012). With this in mind, we will focus on future alternative ways to treat OA.

\section{Autologous Chondrocyte Implantation (ACl)}

Brittberg et al. developed an alternative method to treat local cartilage defects in the knee joints; autologous 
chondrocyte implantation (ACI). It involves harvesting the patient's cells from a healthy and non-weightbearing donor site, the isolation of chondrocytes, i.e., ECM removal, and cell expansion ex vivo to a sufficient number of cells. The cells are then implanted into the damaged area as a cell suspension, covered with a periosteal flap harvested from the patient's tibia (Brittberg et al., 1994). It is, therefore, a two-step surgical procedure. The first trial was performed in humans in 1987 with good clinical outcomes and long-term follow-up (Peterson et al., 2010). Today, the method is widespread and used by surgeons worldwide (Ogura et al., 2017). This first-generation approach has evolved, first by the replacement of the periosteal flap with a collagen membrane (generation II) and then later to cells being grown on a cell carrier (generation III) such as matrixassisted chondrocyte implantation (MACI) (Brittberg et al., 2018), or in a porous scaffold such as Hyalograft (Tognana et al., 2007). After culture, the cell-seeded scaffold is implanted into the defect (Gille et al., 2016). Scaffolds for tissue-engineered cartilage defects are commonly generated from biodegradable natural or synthetic biopolymers. Examples of scaffold materials for this purpose include cellulose, polycaprolactone, hyaluronan, collagens, as well as hydrogels such as agarose and alginate (Nguyen et al., 2011; El-Sherbiny \& Yacoub, 2013). One strategy is to mix gels with rigid materials to create a more rigid scaffold. Liu et al. created a polycaprolactone/gelatin surrounded scaffold to enhance chondrogenesis of mouse iPSCs in vitro and in vivo with a promising outcome (Liu et al., 2014). Several studies have independently reported successful clinical outcomes of the cell-seeded implant approach using arthroscopy for implantation. (Gille et al., 2016; Basad et al., 2015). Although positive clinical outcomes are evident, the two-step surgical implantation process both involves the risk of limited access to autologous chondrocytes, as well as and their harvesting at a healthy donor site resulting in additional injury. Due to the cell expansion in monolayers, chondrocytes tend to dedifferentiate and change phenotype, which affects the synthesis of cartilage-specific matrix proteins essential for regeneration of the implanted chondrocytes (Watt, 1988).

One-stage 4th generation ACI techniques are emerging, and they are increasingly being implemented. Examples include mixing directly isolated chondrocytes with either directly isolated autologous bone marrow stem cells or allogeneic stem cells (Słynarski et al., 2020; de Windt et al., 2017). Particulated or fragmented autologous or allogeneic cartilage as a source for chondrocytes is also regarded as a 4th generation ACI. From crushed cartilage, the most active chondrocytes may migrate out into a surrounding supportive scaffold, gel, or similar (Cole et al., 2011; Grawe et al., 2017).

\section{Microfracture}

An alternative surgical technique for treating local cartilage lesions uses bone marrow stimulations (BMS) such as microfracture. This arthroscopic technique creates small microfractures in the bone under the cartilage defect to trigger a regenerative response from mesenchymal stem cells (MSCs) in the bone marrow. The method is best suited for smaller defects created by trauma and not for OA (Lee et al., 2013). Additionally, younger patients (30-40years old) have shown better outcomes than older patients (Knutsen et al., 2004). This procedure is relatively quick and cost-effective, as well as less invasive than ACI or joint replacements. However, the quality of the repaired MSC-derived cartilage exhibits variations between individuals.

Moreover, high-quality collagen type II-rich hyaline cartilage seems difficult to achieve, and a collagen type I-rich fibrous or hypertrophic cartilage is more likely to be generated (Saris et al., 2008). Despite this, the fibrocartilage might decrease symptoms in the affected joint and reduce pain for the patient. Local chondral and osteochondral lesions are mostly of traumatic origin, while osteoarthritis is an organ disease. A local cartilage lesion, if not treated, may increase in size and lead to OA. For local cartilage lesions, the choice of treatment is mainly based on the size of the lesion. A suggested cartilage lesion local treatment choice is presented here (Brittberg, 2021):

- BMS for small defects $0.5 \mathrm{~cm}^{2}$.

- Augmented BMS for small-medium sized defect $0.6-2 \mathrm{~cm}^{2}$.

- Augmentation is also an alternative for re-operations in such defects if a simple BMS has been done previously.

- Cell based treatments for large defects $>2 \mathrm{~cm}^{2}$.

- Cell based treatments for re-operations $>1 \mathrm{~cm}^{2}$.

- Osteochondral Allografts for extra-large defects.

\section{The drawbacks and possibilities of stem cell origins}

The quality of the cells involved is one drawback of current surgical methods. Researchers are exploring other suitable cell sources that overcome the drawbacks of using autologous-derived chondrocytes to create a functional and healthy hyaline cartilage. Embryonic stem cells (ES-C), MSCs, and iPSC are potential cell sources for understanding $\mathrm{OA}$ disease mechanisms and use in a cell therapy-based treatment. ESCs are pluripotent and can divide infinitely (Takahashi \& Yamanaka, 2006). 
However, problems such as the formation of teratomas and immune rejection have been reported. Such issues complicate the use of ESCs in regenerative medicine. Adult stem cell sources, such as MSCs that can be found in, e.g., bone marrow and adipose tissue, also have the potential to differentiate into several types of tissue (De Bari et al., 2001). The use of MSCs does not require immunosuppression, making them suitable for allogeneic cell banking as well as an off-the-shelf product (Huaman et al., 2019). They are also relatively easy to culture in vitro, as they do not tend to dedifferentiate like chondrocytes (Tallheden et al., 2004). However, MSCs have shown differing proliferation and differentiation capacity, depending on their tissue and molecular microenvironment origin (Maleki et al., 2014). Although MSCs have shown to be safe and efficient in pre-clinical studies, they have a tendency to form hypertrophic chondrocytes and bone instead of hyaline cartilage during chondrogenic differentiation, resulting in impaired biomechanical properties. A genetic discrepancy between articular and MSC-derived chondrocytes has also been detected. It was shown that MSC-derived chondrocytes resulted in a differing cartilage phenotype, and it was concluded that articular chondrocytes and MSCs differentiate along different pathways (Karlsson et al., 2007).

As MSCs are multipotent and can only differentiate into cells within the mesodermal lineage (Pittenger et al., 1999), an alternative cell origin is pluripotent stem cells. Like ESCs, iPSCs are pluripotent, have similar morphology and gene expression profiles, and can be divided infinitely (Takahashi \& Yamanaka, 2006; Liu et al., 2010). iPSCs are a possible cell source with great potential within regenerative medicine and the treatment of cartilage defects and diseases such as OA. The use of iPSCs would overcome any present ethical issues surrounding ESCs, as they can be derived from a minimal number of easily accessible non-invasively harvested somatic cells. Mouse embryonic or adult fibroblasts were first induced to have pluripotency by Takahashi and Yamanaka in 2006 by using retroviruses. Since then, the required factors, Oct3/4, Sox2, Klf4, and c-Myc, have been used to induce pluripotency. These factors combined are known as the Yamanaka factors (Takahashi \& Yamanaka, 2006). An adult cell can thus be reprogrammed back into the pluripotency developmental stage and be differentiated into any mature cell. This makes iPSCs useful in tissue engineering, regenerative medicine, drug screening, toxicity testing, and disease modeling.

One of the Yamanaka factors, C-Myc, is also a known oncogene, which is critical to consider when using iPSCs in clinical applications (Miller et al., 2012). Okita et al. showed how mouse fibroblasts were reprogrammed into iPSCs using the Yamanaka factors. They also discovered tumor generation in chimeric mice after cell transplantation due to the reactivation of the c-Myc gene (Takahashi et al., 2007; Nakagawa et al., 2010). Moreover, due to the pluripotency, there is a possibility that transplanted iPSCs form teratomas in vivo. Therefore, it is essential that no undifferentiated stem cells remain in the transplanted area (Liao et al., 2018). As mentioned, Yamanaka factors were first used to induce pluripotency via retroviruses. By using retroviral reprogramming, the virus' RNA is converted to DNA and integrates with the donor cells' cellular genome, which induces genomic change that can lead to unwanted gene transcription and increase the risk for tumor formation. Therefore, silencing the expression of Oct3/4, Sox2, Klf4, and c-Myc after reprogramming is essential to avoid harmful gene expressions. The use of retroviruses to induce pluripotency and the integrations with the cell genome makes this method unsuitable for human clinical applications (Takahashi \& Yamanaka, 2006; Okita et al., 2007). To improve the reprogramming method, Okita et al. developed a viral-free method circumventing some of the above-mentioned side effects (Okita et al., 2008). A similar footprint-free method has been used to obtain large quantities of fully differentiated astrocytes from iPSCs (Mormone et al., 2014). Concurrently, Boreström, Simonsson et al. have shown that it is possible to eliminate the risk of genomic integrations or aberrations using a genetic footprint-free mRNA delivery system to induce iPSCs chondrogenic redifferentiation (Boreström et al., 2014). This discovery provides a significant step in the procedure to find a suitable cell source for regenerative medicine to treat, e.g., cartilage defects and OA.

The type and source of stem cells are only some aspects to consider when regenerating new and healthy hyaline cartilage. The cell microenvironment, biomolecular signaling, and other aspects of the differentiation process are equally significant issues that must be addressed. During early embryonic development, concentrations and signaling molecules in the cellular microenvironment are crucial, and morphogen gradients are essential inducers for all tissue development, including cartilage (Zecca et al., 1996; Dee et al., 2002; Jullien \& Gurdon, 2005; Peret \& Murphy, 2008). Differentiation into different tissue types can be complex, and the suitable concentration range of specific growth factors is critical (Dakhore et al., 2018). The morphogen gradients involved in the developmental process to engineer functional cartilage may be a potential tool for generating cartilage comparable to the function and strength of native cartilage. Using gradients as such a tool will be discussed further later in this review.

One controversial, due to the mentioned safety issues, question has been raised, especially applicable for cartilage regeneration; whether direct transplantation of 
iPSCs or committed cells at a certain differentiation stage would achieve better outcomes. While developmental immaturity of iPSC-derived cells can be a challenge for tissues like muscle and brain, Lee et al. demonstrate that it can be advantageous for cartilage (Lee et al., 2017a). This idea arises from the fact that particulated juvenile allograft cartilage (PJAC) transplantation has shown better long-term efficacy compared with, e.g., microfractures (Zhang et al., 2021; Adkisson et al., 2010). Nakayama et al. explore the possibility to treat cartilage lesions with iPSCs differentiated into juvenile chondrocytes, aiming to avoid the safety issues but letting the final differentiation to fully mature cells take place after transplantation (Nakayama et al., 2021).

\section{D Bioprinting as scaffolds for local repair}

An upcoming strategy to improve the repair of local cartilage lesions is to use 3D bioprinting to generate a cartilage-like scaffold for the cells. Nguyen et al. concluded that a nanofibrillated cellulose composite bioink combined with alginate printed with human iPSCs and cocultured with irradiated human chondrocytes was well suitable for bioprinting. This combination generated a cartilage-mimicking construct with cells expressing collagen II (Nguyen et al., 2017). One important goal that has yet to be reached with various scaffolds is to replicate the structural and biomechanical properties of native cartilage. 3D bioprinted MSC-containing hydrogels were used as constructs in an in vivo study in mice showing high structural integrity and good mechanical properties (Möller et al., 2017). Trials are also conducted ex vivo, where chondrocytes are 3D bioprinted in situ with promising results (Gatenholm et al., 2020). 3D-bioprinting is a hot topic and is discussed further in other recent reviews (Askari et al., 2021; Wu et al., 2021).

\section{Chondrocyte characterization and validation}

To use stem cell-derived chondrocytes for cartilage regeneration in vivo, the characteristics of chondrocytes must be well-established. Different kinds of experimental setups such as immunoassays, histological assays, microarrays, quantitative polymerase chain reaction (qPCR), and fluorescent-activated cell sorting (FACS) are commonly used in combination with well-known chondrocyte markers such as collagen type II, SOX9, and aggrecan (Tallheden et al., 2004; Lach et al., 2019; Suchorska et al., 2017a). We reviewed articles featuring where ESCs, MSCs, or iPSCs differentiated into the chondrogenic lineage, as well as native chondrocytes, to understand how different research groups characterize chondrocytes and chondroprogenitors. Table 1 shows the four most commonly used experimental methods in the reviewed articles. Other methods used to a minor extent in the publications have been excluded from Table 1 . Based on the reviewed articles, the most commonly used methods to characterize chondrocytes are qPCR, immunostaining, and histological staining that were often used in combination. FACS was used less than the other three assays in the studied articles to obtain supporting data or detect a study-specific marker.

Many of the publications describe new or improved protocols for chondrogenic differentiation of stem cells. Some compare the level of gene expressions with adult chondrocytes (Lach et al., 2019; Suchorska et al., 2017a; Weissenberger et al., 2020; Suchorska et al., 2017b; Diederichs et al., 2019; Adkar et al., 2019; Koyama et al., 2013) . Others choose to compare the increase and decrease of markers within the study samples (Cheng et al., 2014; Oldershaw et al., 2010; Wang et al., 2019; Nejadnik et al., 2015). A high presence of the chondrogenic markers SOX9, COL2, and aggrecan is associated with high-quality articular cartilage regeneration. While the fibro- and hypertrophic cartilage markers, COL1A1, and COL10A1, respectively, should be low (Kamaraj et al., 2021). Also, SOX5, SOX6, COL9, and COL11 are well-known chondrogenic markers. Proteoglycans (Safranin O-staining), Glycosaminoglycans (Alcian Blue-staining), and immunohistochemistry staining for Collagen II are supportive in describing functional cartilage tissue. Other markers mentioned give additional supportive data, e.g., CD44 indicates normal chondrocyte function via connection to hyaluronic acid (Ishida et al., 1997), Hematoxylin and Eosin to visualize tissue cell structures, chondroitin sulfate is a chemical building block of cartilage, and lubricin and COMP indicates a functioning cartilage matrix (Flowers et al., 2017). During the differentiation process, the decrease in expression of pluripotency markers such as OCT4, Nanog, and SOX2 must be measured to ensure the absence of teratoma (Kamaraj et al., 2021).

Tissue engineering projects creating structures that should support the differentiation process can be evaluated using the same markers (Nguyen et al., 2017; Meng et al., 2016; Lu et al., 2017). The markers can also be used when comparing different cell origins after reprogramming them into iPSCs, and then differentiation towards chondrocytes (Rim et al., 2018; Wei et al., 2012). Additional uses are assessing the chondrogenic potential of cells isolated from patients, e.g., for ACI treatment (Tallheden et al., 2004; Naranda et al., 2017), and when studying the signaling pathways of chondrocytes (Enochson et al., 2014).

The characterization and validation are of significant importance to ensure cell specificity and quality. Obtaining high-quality cartilage repairing cells may be possible with an optimized protocol with defined cartilage-specific markers that can provide tight control over 
Table 1 Characterization of chondrocytes or chondroprogenitors

\begin{tabular}{|c|c|c|c|c|c|}
\hline Cell origin & qPCR & Immunostaining & Histology & FACS & Reference \\
\hline ESCS & $\begin{array}{l}\text { COL2, AGGRECAN, SOX9, } \\
\text { SOX6, SOX5, COL9 }\end{array}$ & COL2, SOX9 & $\begin{array}{l}\text { Safranin O, Hematoxylin } \\
\text { and Eosin }\end{array}$ & sox9 & (Cheng et al., 2014) \\
\hline ESCS & $\begin{array}{l}\text { COL2, AGGRECAN, SOX9, } \\
\text { SOX6, SOX5, CD } 44\end{array}$ & COL2, SOX9 & & SOX9, CD44 & (Oldershaw et al., 2010) \\
\hline ESCS & COL2, AGGRECAN, SOX5 & SOX9 & $\begin{array}{l}\text { Safranin O, Hematoxylin } \\
\text { and Eosin }\end{array}$ & SOX9 & (Wang et al., 2019) \\
\hline MSCs & COL2, AGGRECAN, SOX9 & COL2, chondroitin sulfate & $\begin{array}{l}\text { Hematoxylin and Eosin, } \\
\text { Alcian Blue }\end{array}$ & & (Weissenberger et al., 2020) \\
\hline MSCs & COL2, AGGRECAN, SOX9 & COL2 & $\begin{array}{l}\text { Hematoxylin and Eosin, } \\
\text { Alcian Blue, Safranin O }\end{array}$ & CD44 & (Meng et al., 2016) \\
\hline MSCs & COL2, AGGRECAN & COL2, AGGRECAN & Hematoxylin, Alcian Blue & & (Lu et al., 2017) \\
\hline iPSCs+ESCs & COL2, AGGRECAN, SOX9 & $\begin{array}{l}\text { COL2, SOX9, chondroitin } \\
\text { sulfate }\end{array}$ & $\begin{array}{l}\text { Safranin O, Alcian Blue van } \\
\text { Gieson, Toluidine blue, } \\
\text { Hematoxylin, and Eosin }\end{array}$ & & (Lach et al., 2019) \\
\hline iPSCs & COL2, sOX9, sOX6, SOX5 & $\begin{array}{l}\text { COL2, AGGRECAN, SOX9, } \\
\text { SOX6, COL9, COMP }\end{array}$ & & CD44, CD151 & (Suchorska et al., 2017a) \\
\hline iPSCs & $\begin{array}{l}\text { COL2, AGGRECAN, SOX9, } \\
\text { SOX6, COL9, COMP }\end{array}$ & $\begin{array}{l}\text { COL2, AGGRECAN, SOX9, } \\
\text { SOX6, COL9, COMP }\end{array}$ & & & (Suchorska et al., 2017b) \\
\hline iPSCs & COL2, AGGRECAN & COL2, AGGRECAN & Safranin $O$ & & (Diederichs et al., 2019) \\
\hline iPSCs & $\begin{array}{l}\text { COL2, AGGRECAN, SOX9, } \\
\text { COL9, COL11 }\end{array}$ & COL2 & $\begin{array}{l}\text { Alcian Blue, Hematoxylin } \\
\text { and Eosin }\end{array}$ & & (Nejadnik et al., 2015) \\
\hline ¡PSCs & COL2, AGGRECAN, SOX9 & COL2 & $\begin{array}{l}\text { Safranin O, Alcian Blue van } \\
\text { Gieson, Hematoxylin and } \\
\text { Eosin }\end{array}$ & & (Nguyen et al., 2017) \\
\hline iPSCs & $\begin{array}{l}\text { COL2, AGGRECAN, SOX9, } \\
\text { SOX6, SOX5, LUBRICIN }\end{array}$ & COL2 & Toluidine blue & & (Rim et al., 2018) \\
\hline iPSCs & COL2, AGGRECAN, COMP & COL2 & $\begin{array}{l}\text { Toluidine blue, Hematoxy- } \\
\text { lin, and Eosin }\end{array}$ & & (Wei et al., 2012) \\
\hline iPSCs & COL2, AGGRECAN, SOX9 & $\mathrm{COL} 2$ & Safranin $\mathrm{O}$, Hematoxylin & $\begin{array}{l}\text { CD105, CD145, } \\
\text { CD166, CD271 }\end{array}$ & (Adkar et al., 2019) \\
\hline iPSCs & COL2, AGGRECAN, SOX9 & COL2, AGGRECAN & Alcian Blue, Toluidine blue & & (Koyama et al., 2013) \\
\hline Chondrocytes & COL2, AGGRECAN, SOX9 & & Alcian Blue van Gieson & & (Enochson et al., 2014) \\
\hline Chondrocytes & & $\mathrm{COL} 2$ & $\begin{array}{l}\text { Safranin O, Alcian Blue van } \\
\text { Gieson }\end{array}$ & & (Tallheden et al., 2004) \\
\hline Chondrocytes & COL2, AGGRECAN & COL2, AGGRECAN & & & (Naranda et al., 2017) \\
\hline Chondrocytes & COL2, AGGRECAN, COMP & & $\begin{array}{l}\text { Toluidine blue, Hematoxy- } \\
\text { lin, and Eosin }\end{array}$ & & (Wei et al., 2012) \\
\hline
\end{tabular}

Published articles were reviewed to overview how different research groups characterize their chondrocytes or chondroprogenitors originating from differentiated ES, iPSCs, MSCs, or chondrocytes. This table shows targeted genes and proteins in QPCR and immunoassays, histological stainings used, and which antigens were targeted with FACS.

the resulting cell populations. There are advantages and drawbacks to consider depending on the choice of cell source (ESCs, MSCs, iPSCs, and chondrocytes), but all have a high potential for cartilage regeneration. We have reviewed different cell-based products for cartilage regeneration to summarize their current market status and ongoing clinical trials with current methods and problems in mind.

\section{Commercialization of new therapies}

Worldwide, companies are focused on developing cellbased products that repair or regenerate cartilage to amend defects caused by, e.g., OA or trauma. Different strategies have been applied to accomplish this. The well-known ACI method has evolved to include a supporting matrix or scaffold product, aka matrix-associated autologous chondrocyte implantation (MACI). Recently, products that involved the administration of autologous or allogeneic stems cells through intraarticular injection have emerged, either with or without a supporting matrix. Another strategy is to surgically implant 3D biocompatible cell-seeded scaffolds, as described earlier in the review. However, cell-based therapies have been subject to strict regulation by authorities (Reisman \& Adams, 2014) as well as logistical and production challenges. In Table 2, cell-based 


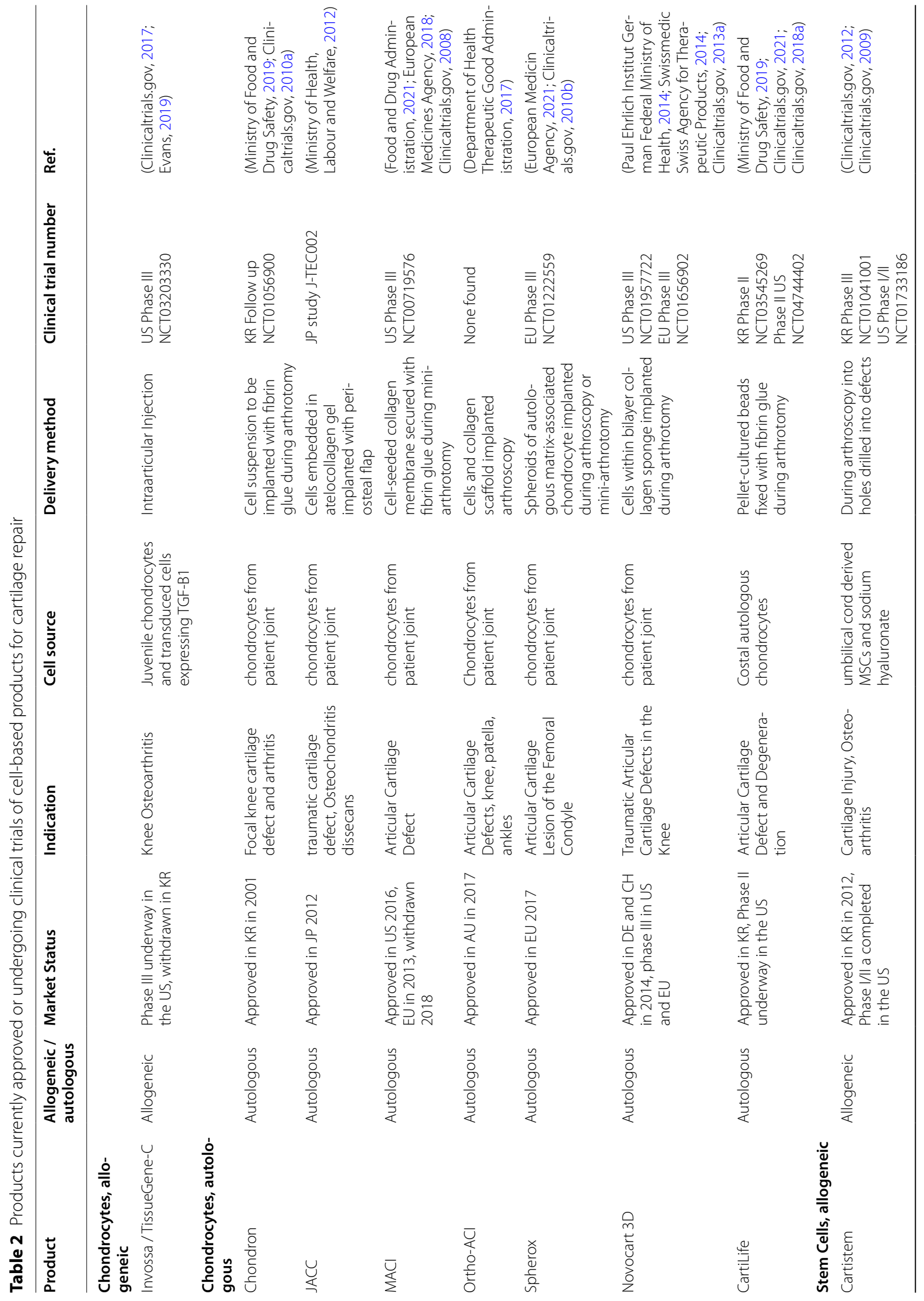




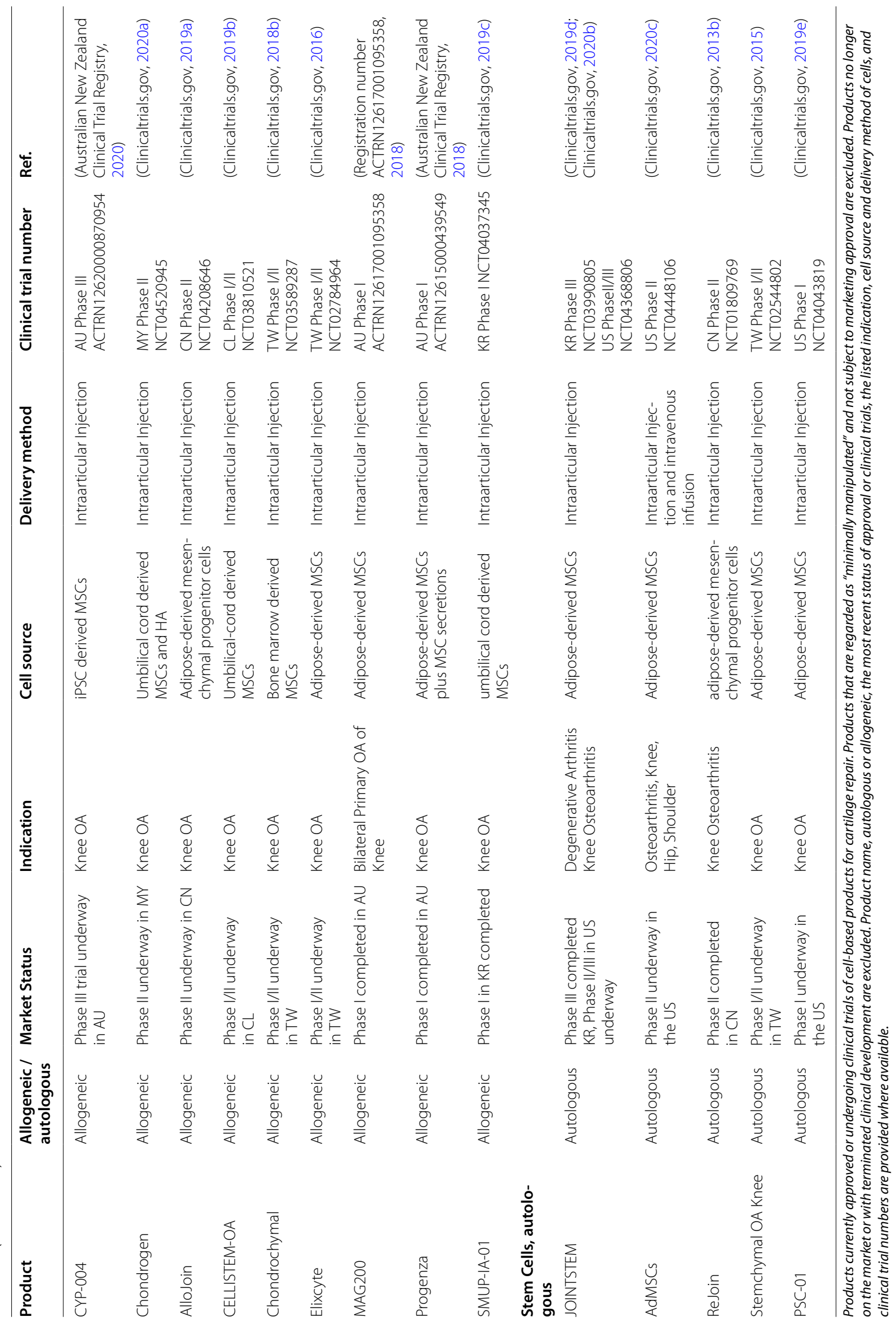


products that are currently approved or within clinical development for the treatment of cartilage damage are summarized.

The earliest approved cell-based products of those reviewed are autologous chondrocyte implantation products. Of the chondrocyte-based products currently approved or in development, the majority are matrixassociated ACI products (JACC, MACI, Ortho-ACI, Spherox, Novocart 3D, Cartlife) where arthroscopically harvested chondrocytes are seeded within a matrix or scaffold material before implantation during a second procedure. These products have largely replaced previous product generations, which involved a liquid cell suspension and the use of a peristomal flap or a collagen membrane, such as Carticel and ChondroCelect (European Medicin Agency, 2017), both having been withdrawn from the market. Recent advances in this area have led to MACI products where cells are cultured to become more cartilage-like and include extracellular components. One example of this is Spherox, which was approved in the EU in 2017 (European Medicin Agency, 2021) following a Phase III clinical trial (NCT01222559) (Clinicaltrials.gov, 2010b). In this product, patient chondrocytes are condensed into spheroids, that is, spherical aggregates of ex vivo expanded chondrocytes with self-synthesized cartilagespecific extracellular matrix (Eschen et al., 2020). Also utilizing the ECM is Cartilife, which is approved in South Korea (Ministry of Food and Drug Safety, 2019) and is currently undergoing a Phase II clinical trial in the US (NCT04744402) (Clinicaltrials.gov, 2021). Cartilife uses costal-derived autologous chondrocytes, which are harvested, expanded, and then undergo a 3-dimensional pellet culture where cells form small beads with immature hyaline cartilage-like ECM (Lee et al., 2017b).

Of the reviewed chondrocyte-based products, there was only one that utilized an allogeneic cell source. Invossa is an intra-articular injection comprised of a combination of juvenile chondrocytes and cells transduced to express TGF- $\beta$ used in knee osteoarthritis. Recently, animal model studies into the potentially disease-modifying mechanisms behind the clinical results showed the treatment in rats caused an increase in anti-inflammatory cytokine IL-10 (Lee et al., 2020). The researchers suggest that the treatment improved OA through the structural improvement and analgesic effects of an anti-inflammatory microenvironment promoted by M2 macrophages, which are known to exhibit immunosuppressive properties within the knee joint (Lee et al., 2020). The product was approved in South Korea in 2017 but withdrawn in 2019. A Phase III Study is underway in the US (NCT03203330) (Clinicaltrials.gov, 2017).

\section{Stem cell-based products}

An increasing number of products are emerging using stem cells such as MSCs and other progenitor cell types. In contrast to ACI, which more often focuses on focal defects, all the reviewed products are indicated for OA. For autologous stem cell products, common cell sources for MSCs are adipose tissue, bone marrow, and peripheral blood. The autologous adipose-derived MSC product JOINTSTEM recently completed a phase III trial (NCT03990805) (Clinicaltrials.gov, 2019d) in South Korea and is conducting a Phase II/III trial in the US (NCT04368806) (Clinicaltrials.gov, 2020b). Additionally, four companies currently are conducting Phase I or Phase II trials (Clinicaltrials.gov, 2020c; Clinicaltrials. gov, 2013b; Clinicaltrials.gov, 2015; Clinicaltrials.gov, 2019e)(NCT04448106, NCT01809769, NCT04043819, NCT02544802). A recent systematic review of randomized controlled trials (RCTs) for autologous stem cell therapy in knee osteoarthritis reviewed 14 RCTs and found a positive effect on patient-reported outcomes. However, they also reported a high risk of bias and low certainty of evidence (Wiggers et al., 2021).

Compared to the autologous stem cell products reviewed, a larger number of products in commercial clinical development were allogeneic. Allogeneic cell sources in Table 2 include adipose tissue, bone marrow, umbilical cord blood, and induced pluripotent stem cells. Allogeneic therapies have the advantage of being "off-theshelf" as opposed to needing to source, transport, and process cells from a patient's bone marrow or adipose tissue in the case of autologous therapy. As mentioned, it is generally accepted that MSCs can be used for allogeneic transplantations without the need for immunosuppression since the MSCs do not display immunogenic properties, which is a key advantage of using MSCs (Huaman et al., 2019).

The first allogeneic MSC product for cartilage injury, Cartistem, was launched in South Korea in 2012 (Ministry of Food and Drug safety, 2016), has conducted a Phase I/II trial in the US (NCT01733186) (Clinicaltrials. gov, 2012). The product combines allogeneic umbilical cord blood-derived MSCs and a hyaluronic acid hydrogel (Park et al., 2017). Unlike all the other reviewed stem cell products, which are intra-articular injections, Cartistem is administered through arthrotomy or arthroscopy with drilling (Park et al., 2017). Medipost, Cartistem's developer, is currently developing a new generation product, an injectable MSC product, SMUP-IA-01, which has completed Phase I clinical trial in Korea (NCT04037345) (Clinicaltrials.gov, 2019c).

Cynata is currently conducting a Phase III study in Australia for CYP-004, an iPSC-derived MSC product (ACTRN12620000870954) (Australian New Zealand 
Clinical Trial Registry, 2020). Uniquely, CYP-004 is manufactured from iPSC cells through the intermediate step mesenchymoangioblasts (MCAs). iPSCs, as a cell source for cartilage regeneration, have some biosafety issues regarding the use in vivo discussed above. Eight other allogeneic stem cell products have completed or are undergoing Phase I or II studies, see Table 2.

\section{The importance of gradients in tissue-mimicking for stem cell therapy development}

For decades, researchers have known about the importance of gradients in developmental biology (Zecca et al., 1996; Dee et al., 2002; Jullien \& Gurdon, 2005; Peret \& Murphy, 2008). Gradients are present in a wide range of biological processes in vivo, including development, inflammation, wound healing, and cancer metastasis. These processes can be studied in vitro using quantifiable and controllable gradients to mimic those present in vivo. In stem cell differentiation and development, the gradients are essential inducers of tissue structure generation and functionality (Zecca et al., 1996; Dee et al., 2002; Jullien \& Gurdon, 2005; Peret \& Murphy, 2008). The local gradients, consisting of biomolecules such as morphogens or growth factors, or physical characteristics such as stiffness gradients, are involved in cell regulation and the inducement of developmental processes (Zecca et al., 1996; Dakhore et al., 2018; Gurdon et al., 1994; Gurdon et al., 1998; Joaquin et al., 2016). Only a few articles have managed to visualize morphogen gradients in vivo or in vitro (Teleman \& Cohen, 2000; Lagunas et al., 2013). However, as technology develops, different gradient setups have been increasingly employed to study stem cells.
As gradient-regulated processes are present in various signaling systems throughout the cell surroundings, there are different approaches to how they are used depending on the aim of the study. It is also important to consider the scale and the level of precision available, from a macro scale down to influencing cells on a nano- or molecular level. The most studied gradual cell environment factors are stiffness, chemical/cell attachment, and biomolecular (e.g., morphogens, growth factors). Such studies aim to study migration, differentiation, cell proliferation, and growth optimization. The choice of approach varies and can overlap. Examples of types of gradients are hydrogels, microfluidics, nano-gradients, and plasmatreated polymer surfaces. Table 3 summarizes the literature on these approaches. There are drawbacks and benefits with all strategies, and in some cases combining techniques may be a successful alternative, depending on the aim of the study.

Regarding stem cell differentiation towards chondrocytes, little research is published around biomolecular gradients and their influence on differentiation despite the evident importance during tissue development (Jullien \& Gurdon, 2005; Gurdon \& Bourillot, 2001). The primary focus has been stiffness gradients based on mimicking the complex zonal microstructure of cartilage tissue. According to Idazec et al., current clinical treatments fail to regenerate new tissue that recapitulates this zonal structure resulting in the regenerated tissue lacking long-term stability (Idaszek et al., 2019). The study used a microfluidic printing device to shape gradients of chemical, mechanical, and biological factors into a layered cartilage-like structure in which MSCs and chondrocytes

Table 3 Summary of gradient technologies and their use in cell applications

\begin{tabular}{|c|c|c|c|c|}
\hline $\begin{array}{l}\text { Technology } \\
\text { Type of gradient }\end{array}$ & Hydrogel & Microfluidics & $\begin{array}{l}\text { Plasma polymer/ polymer } \\
\text { surface }\end{array}$ & Nano-gradient \\
\hline Stiffness & $\begin{array}{l}\text { Migration (Kim et al., 2015), } \\
\text { Differentiation (Oh et al., } \\
\text { 2016), } \\
\text { Other cell behavior (Hadden } \\
\text { et al., 2017; Idaszek et al., 2019) }\end{array}$ & NA & NA & No studies found \\
\hline Chemical/Attachment & $\begin{array}{l}\text { Other cell behavior (Idaszek } \\
\text { et al., 2019) }\end{array}$ & NA & $\begin{array}{l}\text { Differentiation (Liu et al., 2015; } \\
\text { Wang et al., 2015) }\end{array}$ & No studies found \\
\hline Biomolecular & $\begin{array}{l}\text { Culturing/Growth (Mahadik } \\
\text { et al., 2014), } \\
\text { Migration (Addington et al., } \\
\text { 2015), } \\
\text { Differentiation (O'Grady et al., } \\
\text { 2019; Smith Callahan et al., } \\
\text { 2013), } \\
\text { Other cell behavior (Idaszek } \\
\text { et al., 2019) }\end{array}$ & $\begin{array}{l}\text { Culturing/Growth (Mahadik } \\
\text { et al., 2014), } \\
\text { Migration (Won et al., } \\
\text { 2014), } \\
\text { Differentiation (O'Grady } \\
\text { et al., 2019; Chung et al., } \\
\text { 2005) }\end{array}$ & $\begin{array}{l}\text { Culturing/Growth (Faia-Torres } \\
\text { et al., 2015; Miller et al., 2011), } \\
\text { Other cell behavior (Harding } \\
\text { et al., 2012) }\end{array}$ & $\begin{array}{l}\text { Differentiation (Andreasson } \\
\text { et al., 2020a; Andreasson et al., } \\
\text { 2020b) }\end{array}$ \\
\hline
\end{tabular}

The reviewed literature is listed in the table to summarize the technology, type of gradient used, and what it was aimed to study. Gradient technology is indicated horizontally and gradient type vertically. The studied cellular responses are grouped into migration, differentiation, culturing/growth, and other cell behavior that vary significantly and are specific for each study. 
were co-cultured (Idaszek et al., 2019). This layered structure approach has been investigated and created in multiple ways using microfluidics, hydrogels, electrospun fibrous meshes, and cell sheets (Nguyen et al., 2011; Jin et al., 2019; Shi et al., 2013). Hydrogel stiffness gradients have also been used for investigating favorable stiffness ranges for induction of differentiation into specific cell types (Oh et al., 2016). All these techniques have their respective benefits and drawbacks depending on their use. However, they all aim to demonstrate how mechanical cues and loads control stem cell differentiation and tissue regeneration. Such studies are of great importance as it has been found that externally applied mechanical forces can stimulate stem cells to promote tissue regeneration (Enochson et al., 2014).

Nano-gradient technology offers a platform with an extensive range of biomolecule binding possibilities, providing a broad potential to gain knowledge of differentiation and cell-protein interactions. Moreover, the technology provides new opportunities to elucidate dose-dependent events, such as inducing migratory behavior. The nano-gradients are gradients of activator molecules bound to gold nanoparticles precisely distributed on a surface. They provide a unique chemically and physically defined substrate for controlled culture systems with a highly reproducible capacity (Andreasson et al., 2020a; Andreasson et al., 2020b; Lundgren et al., 2014; Evenbratt et al., 2020). One purpose of using gold nanoparticles is to present growth factors in a controlled manner to the cells. As the cells are immobilized on a surface, stimulations are comparable to in vivo conditions with matrix-bound cells, where local concentrations influence them (Fig. 1). These precise and stable molecular gradients enable dictating cell responses during differentiation because of the defined surface composition, density, and slope on a nano-level
(Andreasson et al., 2020a; Andreasson et al., 2020b; Lundgren et al., 2014; Evenbratt et al., 2020).

The nano-gradients also allow the opportunity to combine factors, e.g., a growth factor with an ECM protein, further mimicking in vivo conditions, combining other materials and technologies, and forming a step in the differentiation protocol from where the cells can be removed and further cultured. The nano-gradient technology allows for screening an optimal growth factor density providing a robust differentiation protocol due to a precise and controlled stimulation, compared to, e.g., a solution-based gradient where growth factors are constantly moving (Minchiotti et al., 2006). Involving the gradient in differentiation protocols to generate chondrocyte progenitors could improve the ability to yield a defined cell population for differentiation before implantation into a damaged cartilage area (Andreasson et al., 2020a). However, further research is needed.

All stem cell research and therapeutic applications, such as tissue regeneration, require defined and stable protocols to precisely control the cells during differentiation, but also to maintain required cellular properties and simultaneously mimic in vivo conditions. Stem cell cultures for therapy require high cell quality and a homogeneous cell population; however, traditional 2D cultures provide limited expansion and differentiation capacity (Zhang et al., 2004). As mentioned, concentration gradients in vivo enable regulation of cell responses, which are necessary for the function and structure during tissue generation in embryonic development (Zecca et al., 1996; Peret \& Murphy, 2008). Such gradients are essential inducers of many developmental and articular cartilage-generating processes.
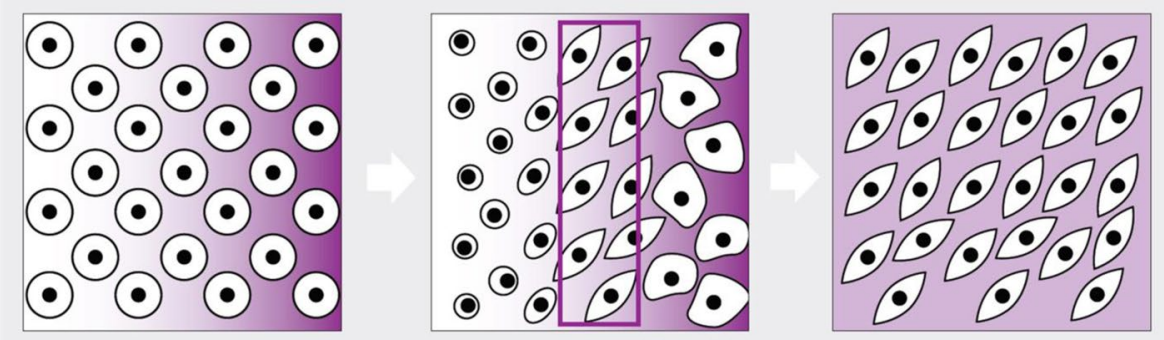

Fig. 1 The figure is a schematic image of the use of gradient nanotechnology in cell differentiation. The cells are seeded on a gradient surface (left), and the differentiation process reveals an optimal cell population (middle). A specific molecular density surface provides optimal, homogenous cell populations (right), a possibility owed to the information gathered on the gradient 


\section{Conclusion}

Current treatments of local cartilage lesions and OA focus on reducing pain and inflammation with insufficient long-term results. Today, no treatment is focused on disease-modifying mechanisms, and cell-based therapies struggle to generate high-quality cartilage. MSCs have become a commonly used cell source in developing approved and generally accepted stem cell therapy. Many companies have ongoing or completed clinical trials with promising results despite possible drawbacks, such as MSCs tending to form hypertrophic chondrocytes and bone instead of high-quality hyaline cartilage during chondrogenic differentiation. iPSC-derived chondrocytes have emerged as a potential alternative to MSCs, overcoming many of their drawbacks. However, issues, such as safety, have not been fully investigated to successfully commercialize iPSCbased treatments. To our knowledge, only one iPSCbased therapy for OA is in the clinical phase, currently undergoing a significant phase III trial. Biomolecular gradients are a potential aid to overcome problems with the differentiation of iPSCs. Gradients are essential in embryonic development. By utilizing gradients in the differentiation protocols, it is possible to provide a defined molecular stimulation to the cells and increase robustness compared to earlier protocols. A stable and more robust gradient would theoretically aid in generating a defined cell population for implantation into the damaged cartilage area. Further research, however, is required to accomplish this. Nonetheless, the research and development in this area are rapidly evolving in the quest to use stem cell-based therapies to treat cartilage damage.

\section{Abbreviations \\ OA: Osteoarthritis; iPSCs: Induced pluripotent stem cells; ECM: Extracellular matrix; ACl: Autologous chondrocyte implantation; MACl: Matrix-assisted chondrocyte implantation; 3D: Three-dimensional; MSCs: Mesenchymal stem cells; ESCs: Embryonic stem cells; BMS: Bone marrow stimulation; PJAC: Particulated juvenile allograft cartilage; qPCR: Quantitative polymerase chain reaction; FACS: Fluorescent-activated cell sorting; RCT: Randomized controlled trials.}

\section{Acknowledgments}

Not applicable.

\section{Authors' contributions}

HE and LA were major contributors in writing the manuscript. VB analyzed the companies focused on cell-based therapies for cartilage regeneration that have entered clinical trials. RM and SS contributed with cell expertise, SS specifically on cartilage regeneration. MB provided clinical expertise and mechanistic information on treatments. All authors read and approved the final manuscript.

\section{Funding}

Most funding by Cline Scientific $A B$ and partly funded by the European Union's Horizon 2020 research and innovation program under grant agreement RESTORE no 814558 and AUTOCRAT no 874671.
Availability of data and materials

Not applicable.

\section{Declarations}

Ethics approval and consent to participate

Not applicable.

\section{Consent for publication \\ Not applicable.}

\section{Competing interests}

$H E, L A, V B, R M$ are employed by Cline Scientific $A B$, and $H E$ also holds stock in the company. The authors have no additional competing financial interests.

\section{Author details}

${ }^{1}$ Cline Scientific AB, SE-431 53 MöIndal, Sweden. ${ }^{2}$ Institute of Biomedicine at Sahlgrenska Academy, Department of Clinical Chemistry and Transfusion Medicine, University of Gothenburg, SE-413 45 Gothenburg, Sweden. ${ }^{3}$ Cartilage Research Unit, University of Gothenburg, Region Halland Orthopaedics, Kungsbacka Hospital, S-434 80 Kungsbacka, Sweden.

Received: 27 May 2021 Accepted: 6 December 2021

Published online: 02 February 2022

\section{References}

Addington CP, Heffernan JM, Millar-Haskell CS, Tucker EW, Sirianni RW, Stabenfeldt SE. Enhancing neural stem cell response to SDF-1a gradients through hyaluronic acid-laminin hydrogels. Biomaterials. 2015;72:11-9. https://doi.org/10.1016/j.biomaterials.2015.08.041.

Adkar SS, Wu C-L, Willard VP, et al. Step-Wise Chondrogenesis of Human Induced Pluripotent Stem Cells and Purification Via a Reporter Allele Generated by CRISPR-Cas9 Genome Editing. Stem Cells. 2019;37(1):6576. https://doi.org/10.1002/stem.2931.

Adkisson HD, Martin JA, Amendola RL, et al. The Potential of Human Allogeneic Juvenile Chondrocytes for Restoration of Articular Cartilage. Am J Sports Med. 2010;38(7):1324-33. https://doi.org/10.1177/0363546510 361950.

Agarwal N, Mak C, Bojanic C, To K, Khan W. Meta-Analysis of Adipose Tissue Derived Cell-Based Therapy for the Treatment of Knee Osteoarthritis. Cells. 2021;10(6):1365. https://doi.org/10.3390/cells10061365.

Andreasson L, Evenbratt H, Mobini R, Simonsson S. Differentiation of induced pluripotent stem cells into definitive endoderm on Activin A-functionalized gradient surfaces. J Biotechnol Published online November 2020b. doi:https://doi.org/10.1016/j.jbiotec.2020.10.030.

Andreasson L, Evenbratt $H$, Simonsson S. GDF5 induces TBX3 in a concentration dependent manner - on a gold nanoparticle gradient. Heliyon. 2020a;6(6):e04133. https://doi.org/10.1016/j.heliyon.2020.e04133.

Askari M, Afzali Naniz M, Kouhi M, Saberi A, Zolfagharian A, Bodaghi M. Recent progress in extrusion 3D bioprinting of hydrogel biomaterials for tissue regeneration: a comprehensive review with focus on advanced fabrication techniques. Biomater Sci. 2021;9(3):535-73. https://doi.org/10. 1039/D0BM00973C.

Australian New Zealand Clinical Trial Registry [Internet]. Registration number ACTRN12615000439549, Phase 1 Randomised, Double Blind, Placebo Controlled, Single Ascending Dose Study to Evaluate the Safety, Tolerability and Preliminary Efficacy of Intra-ar. Published 2018. Accessed March 15, 2021. http://www.anzctr.org.au/Trial/Registration/TrialReview. aspx?id $=368355$

Australian New Zealand Clinical Trial Registry [Internet]. Registration number ACTRN12620000870954, Evaluating the efficacy and cost-effectiveness of stem cell injections in people with mild to moderate knee osteoarthritis: a randomised placebo-controlled. Published 2020. Accessed March 15, 2021. http://anzctr.org.au/Trial/Registration/TrialReview.aspx? ACTRN $=12620000870954$

Basad E, Wissing FR, Fehrenbach P, Rickert M, Steinmeyer J, Ishaque B. Matrixinduced autologous chondrocyte implantation (MACl) in the knee: 
clinical outcomes and challenges. Knee Surg Sports Traumatol Arthrosc 2015;23(12):3729-35. https://doi.org/10.1007/s00167-014-3295-8.

Boreström C, Simonsson S, Enochson L, et al. Footprint-free human induced pluripotent stem cells from articular cartilage with redifferentiation capacity: a first step toward a clinical-grade cell source. Stem Cells Transl Med. 2014;3(4):433-47. https://doi.org/10.5966/sctm.2013-0138.

Brittberg M. The chondrocyte;still valuable for cartilage repair. Sport Med J. 2021;10:150-5 https://www.aspetar.com/journal/viewarticle.aspx?id= 527.

Brittberg M, Lindahl A, Nilsson A, Ohlsson C, Isaksson O, Peterson L. Treatment of deep cartilage defects in the knee with autologous chondrocyte transplantation. N Engl J Med. 1994;331 (14):889-95. https://doi.org/10. 1056/NEJM199410063311401.

Brittberg M, Recker D, Ilgenfritz J, Saris DBF. Matrix-Applied Characterized Autologous Cultured Chondrocytes Versus Microfracture: Five-Year Follow-up of a Prospective Randomized Trial. Am J Sports Med. 2018;46(6):1343-51. https://doi.org/10.1177/0363546518756976.

Chen A, Gupte C, Akhtar K, Smith P, Cobb J. The Global Economic Cost of Osteoarthritis: How the UK Compares. Arthritis. 2012;2012:698709. https://doi.org/10.1155/2012/698709.

Cheng A, Kapacee Z, Peng J, et al. Cartilage repair using human embryonic stem cell-derived chondroprogenitors. Stem Cells Transl Med. 2014;3(11):1287-94. https://doi.org/10.5966/sctm.2014-0101.

Chung BG, Flanagan LA, Rhee SW, et al. Human neural stem cell growth and differentiation in a gradient-generating microfluidic device. Lab Chip. 2005;5(4):401-6. https://doi.org/10.1039/b417651k.

Clinicaltrials.gov [Internet]. Identifier NCT00719576. Superiority of MACl ${ }^{\circledR}$ Versus Microfracture Treatment in Patients With Symptomatic Articular Cartilage Defects in the Knee (SUMMIT). Published 2008. Accessed September 16, 2021. https://clinicaltrials.gov/ct2/show/NCT00719576

Clinicaltrials.gov [Internet]. Identifier NCT01041001 Study to Compare Efficacy and Safety of Cartistem and Microfracture in Patients With Knee Articular Cartilage Injury. Published 2009. Accessed September 16, 2021. https://clinicaltrials.gov/ct2/show/NCT01041001

Clinicaltrials.gov [Internet]. Identifier NCT01056900 Observation of the Result After Chondron (Autologous Chondrocytes) Treatment. Published 2010a. Accessed September 16, 2021. https://clinicaltrials.gov/ct2/ show/NCT01056900

Clinicaltrials.gov [Internet]. Identifier NCT01222559 Efficacy and Safety Study of co. Don Chondrosphere to Treat Cartilage Defects. Published 2010b. Accessed September 16, 2019. https://clinicaltrials.gov/ct2/show/ NCT01222559

Clinicaltrials.gov [Internet]. Identifier NCT01733186 Evaluation of Safety and Exploratory Efficacy of CARTISTEM ${ }^{\circledR}$, a Cell Therapy Product for Articular Cartilage Defects. Published 2012. Accessed September 16, 2021. https://clinicaltrials.gov/ct2/show/NCT01733186

Clinicaltrials.gov [Internet]. Identifier NCT01957722 NOVOCART ${ }^{\circledR} 3$ D for Treatment of Articular Cartilage of the Knee (N3D). Published 2013a. Accessed September 16, 2019. https://clinicaltrials.gov/ct2/show/ NCT01957722

Clinicaltrials.gov [Internet]. Identifier NCT01809769, Autologous Adipose Tissue Derived Mesenchymal Stem Cells Therapy for Patients With Knee Osteoarthritis. Published 2013b. Accessed September 16, 2021. https:// clinicaltrials.gov/ct2/show/NCT01809769

Clinicaltrials.gov [Internet]. Identifier NCT02544802, Mesenchymal Stem Cell Treatment for Primary Osteoarthritis Knee. Published 2015. Accessed September 16, 2021. https://clinicaltrials.gov/ct2/show/NCT02544802

Clinicaltrials.gov [Internet]. Identifier NCT02784964, Adipose-derived Stem Cells (ADSCs) for Knee Osteoarthritis. Published 2016. Accessed September 16, 2021. https://clinicaltrials.gov/ct2/show/NCT02784964

Clinicaltrials.gov [Internet]. Identifier NCT03203330, A Study to Determine the Safety and Efficacy of TG-C in Subjects With Kellgren and Lawrence Grade 2 or 3 OA of the Knee. Published 2017. Accessed September 16, 2021. https://clinicaltrials.gov/ct2/show/NCT03203330

Clinicaltrials.gov [Internet]. Identifier NCT03545269 Ph Study to Assess the Efficacy and Safety of Treatment of Articular Cartilage Lesions With CartiLife ${ }^{\circledR}$ Available from. Published 2018a. Accessed September 16, 2021. https://clinicaltrials.gov/ct2/show/NCT03545269

Clinicaltrials.gov [Internet]. Identifier NCT03589287, Allogeneic Bone Marrow MSC Therapy for Knee Osteoarthritis. Published 2018b. Accessed September 16, 2021. https://clinicaltrials.gov/ct2/show/NCT03589287
Clinicaltrials.gov [Internet]. Identifier NCT04208646, Allogenic Adipose TissueDerived Mesenchymal Progenitor Cells for the Treatment of Knee Osteoarthritis. Published 2019a. Accessed September 16, 2021. https:// clinicaltrials.gov/ct2/show/NCT04208646

Clinicaltrials.gov [Internet]. Identifier NCT03810521, Dose-escalation of Cellistem-OA in Patients With Knee Osteoarthritis (CLT-OA1). Published 2019b. Accessed September 16, 2021. https://clinicaltrials.gov/ct2/ show/NCT03810521

Clinicaltrials.gov [Internet]. Identifier NCT04037345. A Phase 2b/3a Study to Evaluate the Efficacy and Safety of JointStem in Patients Diagnosed as Knee Osteoarthritis. Published 2019c. Accessed September 16, 2021. https://clinicaltrials.gov/ct2/show/NCT04037345

Clinicaltrials.gov [Internet]. Identifier NCT03990805, A Phase 3 Study to Evaluate the Efficacy and Safety of JointStem in Treatment of Osteoarthritis. Published 2019d. Accessed September 16, 2021. https://clinicaltrials. gov/ct2/show/NCT03990805

Clinicaltrials.gov [Internet]. Identifier NCT04043819, Evaluation of Safety and Exploratory Efficacy of an Autologous Adipose-derived Cell Therapy Product for Treatment of Single Knee Osteoarthritis. Published 2019e. Accessed September 16, 2021. https://clinicaltrials.gov/ct2/show/ NCT04043819

Clinicaltrials.gov [Internet]. Identifier NCT04520945, Phase 2B Clinical Study of Chondrogen for Treatment of Knee Osteoarthritis. Published 2020a. Accessed September 16, 2021. https://clinicaltrials.gov/ct2/show/ NCT04520945

Clinicaltrials.gov [Internet]. Identifier NCT04368806 A Phase 2b/3a Study to Evaluate the Efficacy and Safety of JointStem in Patients Diagnosed as Knee Osteoarthritis. Published 2020b. Accessed September 16, 2021. https://clinicaltrials.gov/ct2/show/NCT04368806

Clinicaltrials.gov [Internet]. Identifier NCT04448106, Autologous Adipose Tissue-Derived Mesenchymal Stem Cells (AdMSCs) for Osteoarthritis (AdMSCs). Published 2020c. Accessed September 16, 2021. https://clini caltrials.gov/ct2/show/NCT04448106

Clinicaltrials.gov [Internet]. Identifier NCT04744402 Phase 2 Clinical Trial of CartiLife ${ }^{\circledR}$ in the United States. Accessed September 16, 2021. https:// clinicaltrials.gov/ct2/show/NCT04744402

Cole BJ, Farr J, Winalski CS, et al. Outcomes After a Single-Stage Procedure for Cell-Based Cartilage Repair. Am J Sports Med. 2011;39(6):1170-9. https://doi.org/10.1177/0363546511399382.

Dakhore S, Nayer B, Hasegawa K. Human Pluripotent Stem Cell Culture: Current Status, Challenges, and Advancement. Stem Cells Int. 2018:2018:7396905. https://doi.org/10.1155/2018/7396905.

De Bari C, Dell'Accio F, Tylzanowski P, Luyten FP. Multipotent mesenchymal stem cells from adult human synovial membrane. Arthritis Rheum. 2001:44(8):1928-42.

de Windt TS, Vonk LA, Slaper-Cortenbach ICM, et al. Allogeneic Mesenchymal Stem Cells Stimulate Cartilage Regeneration and Are Safe for Single-Stage Cartilage Repair in Humans upon Mixture with Recycled Autologous Chondrons. Stem Cells. 2017;35(1):256-64. https://doi.org/ 10.1002/stem.2475.

Dee KC, Puleo DA, Bizios R. An Introduction To Tissue-Biomaterial Interactions. John Wiley \& Sons, Inc.; 2002. doi:https://doi.org/10.1002/0471270598.

Department of Health Therapeutic Good Administration [Internet]. Public Summary 289402 Cellular Therapies - Chondrocytes - T - Ortho-ACI - Orthocell Pty Ltd - Suspension - Vial. Published 2017. Accessed September 16, 2021. https://www.ebs.tga.gov.au/servlet/xmlmillr6? dbid=ebs/PublicHTML/pdfStore.nsf\&docid=289402\&agid=(PrintDet ailsPublic).

Diederichs S, Klampfleuthner FAM, Moradi B, Richter W. Chondral Differentiation of Induced Pluripotent Stem Cells Without Progression Into the Endochondral Pathway. Front cell Dev Biol. 2019;7:270. https://doi.org/ 10.3389/fcell.2019.00270.

El-Sherbiny IM, Yacoub MH. Hydrogel scaffolds for tissue engineering: Progress and challenges. Glob Cardiol Sci Pract. 2013;2013(3):316-42. https://doi. org/10.5339/gcsp.2013.38.

Enochson L, Stenberg J, Brittberg M, Lindahl A. GDF5 reduces MMP13 expression in human chondrocytes via DKK1 mediated canonical Wnt signaling inhibition. Osteoarthr Cartil. 2014;22(4):566-77. https://doi.org/10. 1016/j.joca.2014.02.004

Eschen C, Kaps C, Widuchowski W, et al. Clinical outcome is significantly better with spheroid-based autologous chondrocyte implantation 
manufactured with more stringent cell culture criteria. Osteoarthr Cartil Open. 2020;2(1):100033. https://doi.org/10.1016/j.ocarto.2020.100033.

European Medicin Agency [Internet]. ChondroCelect characterised viable autologous cartilage cells expanded ex vivo expressing specific marker proteins. Published 2017. Accessed September 16, 2021. https://www. ema.europa.eu/en/medicines/human/EPAR/chondrocelect

European Medicin Agency [Internet]. Spherox spheroids of human autologous matrix-associated chondrocytes. Published gercy. Accessed September 16, 2021. https://www.ema.europa.eu/en/medicines/human/EPAR/ chondrocelect

European Medicines Agency [Internet]. Maci matrix-applied characterised autologous cultured chondrocytes. Published 2018. Accessed September 16, 2021. https://www.ema.europa.eu/en/medicines/human/EPAR/ maci

Evans CH. The vicissitudes of gene therapy. Bone Joint Res. 2019;8(10):469-71. https://doi.org/10.1302/2046-3758.810.BJR-2019-0265.

Evenbratt H, Munem M, Malmberg P. ToF-SIMS imaging of dual biomolecular monolayer gradients. Biointerphases. 2020;15(6):061014. https://doi. org/10.1116/6.0000621.

Faia-Torres AB, Goren T, Ihalainen TO, et al. Regulation of human mesenchymal stem cell osteogenesis by specific surface density of fibronectin: a gradient study. ACS Appl Mater Interfaces. 2015;7(4):2367-75. https:// doi.org/10.1021/am506951c

Flowers SA, Zieba A, Örnros J, et al. Lubricin binds cartilage proteins, cartilage oligomeric matrix protein, fibronectin and collagen II at the cartilage surface. Sci Rep. 2017;7(1):13149. https://doi.org/10.1038/ s41598-017-13558-y.

Food and Drug Administration [Internet]. MACl (Autologous Cultured Chondrocytes on a Porcine Collagen Membrane). Published 2021. Accessed September 16, 2021. https://www.fda.gov/vaccines-blood-biologics/ cellular-gene-therapy-products/maci-autologous-cultured-chondrocyt es-porcine-collagen-membrane

Fosang AJ, Stanton H, Little CB, Atley LM. Neoepitopes as biomarkers of cartilage catabolism. Inflamm Res. 2003;52(7):277-82. https://doi.org/ 10.1007/s00011-003-1177-5.

Frazer A, Bunning RA, Thavarajah M, Seid JM, Russell RG. Studies on type II collagen and aggrecan production in human articular chondrocytes in vitro and effects of transforming growth factor-beta and interleukin1 beta. Osteoarthr Cartil. 1994;2(4):235-45. https://doi.org/10.1016/ s1063-4584(05)80075-5.

Gatenholm B, Lindahl C, Brittberg M, Simonsson S. Collagen 2A Type B Induction after 3D Bioprinting Chondrocytes In Situ into Osteoarthritic Chondral Tibial Lesion. Cartilage. Published online February 18, 2020:194760352090378. doi:https://doi.org/10.1177/1947603520 903788

Gille J, Behrens P, Schulz AP, Oheim R, Kienast B. Matrix-Associated Autologous Chondrocyte Implantation. Cartilage. 2016;7(4):309-15. https://doi.org/ 10.1177/1947603516638901.

Goh EL, Lou WCN, Chidambaram S, Ma S. The role of joint distraction in the treatment of knee osteoarthritis: a systematic review and quantitative analysis. Orthop Res Rev. 2019;11:79-92. https://doi.org/10.2147/ORR. S211060.

Grawe B, Burge A, Nguyen J, et al. Cartilage Regeneration in Full-Thickness Patellar Chondral Defects Treated with Particulated Juvenile Articular Allograft Cartilage: An MRI Analysis. Cartilage. 2017;8(4):374-83. https:// doi.org/10.1177/1947603517710308

Gurdon JB, Bourillot PY. Morphogen gradient interpretation. Nature. 2001;413(6858):797-803. https://doi.org/10.1038/35101500.

Gurdon JB, Dyson S, St JD. Cells' perception of position in a concentration gradient. Cell. 1998;95(2):159-62. https://doi.org/10.1016/s0092-8674(00) 81747-x.

Gurdon JB, Harger P, Mitchell A, Lemaire P. Activin signalling and response to a morphogen gradient. Nature. 1994;371(6497):487-92. https://doi.org/ 10.1038/371487a0.

Hadden WJ, Young JL, Holle AW, et al. Stem cell migration and mechanotransduction on linear stiffness gradient hydrogels. Proc Natl Acad Sci U S A. 2017;114(22):5647-52. https://doi.org/10.1073/pnas.1618239114.

Haq I, Murphy E, Dacre J. Osteoarthritis. Postgrad Med J. 2003;79(933):377-83. https://doi.org/10.1136/pmj.79.933.377.

Harding FJ, Clements LR, Short RD, Thissen H, Voelcker NH. Assessing embryonic stem cell response to surface chemistry using plasma polymer gradients. Acta Biomater. 2012;8(5):1739-48. https://doi.org/10.1016/j. actbio.2012.01.034

Hiligsmann M, Reginster JY. The economic weight of osteoarthritis in Europe Medicographia. 2013;35:197-202.

Huaman O, Bahamonde J, Cahuascanco B, et al. Immunomodulatory and immunogenic properties of mesenchymal stem cells derived from bovine fetal bone marrow and adipose tissue. Res Vet Sci. 2019;124:212-22. https://doi.org/10.1016/j.rvsc.2019.03.017.

Hudetz D, Borić I, Rod E, et al. The Effect of Intra-articular Injection of Autologous Microfragmented Fat Tissue on Proteoglycan Synthesis in Patients with Knee Osteoarthritis. Genes (Basel). 2017;8(10). https://doi.org/10. 3390/genes8100270.

Idaszek J, Costantini M, Karlsen TA, et al. 3D bioprinting of hydrogel constructs with cell and material gradients for the regeneration of full-thickness chondral defect using a microfluidic printing head. Biofabrication. 2019;11(4):044101. https://doi.org/10.1088/1758-5090/ab2622.

Ishida O, Tanaka Y, Morimoto I, Takigawa M, Eto S. Chondrocytes Are Regulated by Cellular Adhesion Through CD44 and Hyaluronic Acid Pathway. J Bone Miner Res. 1997;12(10):1657-63. https://doi.org/10.1359/jbmr. 1997.12.10.1657.

Jin L, Zhao W, Ren B, et al. Osteochondral tissue regenerated via a strategy by stacking pre-differentiated BMSC sheet on fibrous mesh in a gradient. Biomed Mater. 2019;14(6):065017. https://doi.org/10.1088/1748-605X/ ab49e2.

Joaquin D, Grigola M, Kwon G, et al. Cell migration and organization in threedimensional in vitro culture driven by stiffness gradient. Biotechnol Bioeng. 2016;113(11):2496-506. https://doi.org/10.1002/bit.26010.

Jullien J, Gurdon J. Morphogen gradient interpretation by a regulated trafficking step during ligand-receptor transduction. Genes Dev. 2005;19(22):2682-94. https://doi.org/10.1101/gad.341605.

Kamaraj A, Kyriacou H, Seah KTM, Khan WS. Use of human induced pluripotent stem cells for cartilage regeneration in vitro and within chondral defect models of knee joint cartilage in vivo: a Preferred Reporting Items for Systematic Reviews and Meta-Analyses systematic literature review. Cytotherapy. 2021;23(8):647-61. https://doi.org/10.1016/j.jcyt.2021.03. 008.

Karlsson C, Brantsing C, Svensson T, et al. Differentiation of human mesenchymal stem cells and articular chondrocytes: analysis of chondrogenic potential and expression pattern of differentiation-related transcription factors. J Orthop Res. 2007;25(2):152-63. https://doi.org/10.1002/jor. 20287.

Kim TH, An DB, Oh SH, Kang MK, Song HH, Lee JH. Creating stiffness gradient polyvinyl alcohol hydrogel using a simple gradual freezing-thawing method to investigate stem cell differentiation behaviors. Biomaterials. 2015:40:51-60. https://doi.org/10.1016/j.biomaterials.2014.11.017.

Knutsen G, Engebretsen L, Ludvigsen TC, et al. Autologous chondrocyte implantation compared with microfracture in the knee. A randomized trial. J Bone Joint Surg Am. 2004;86(3):455-64. https://doi.org/10.2106/ 00004623-200403000-00001.

Koyama N, Miura M, Nakao K, et al. Human induced pluripotent stem cells differentiated into chondrogenic lineage via generation of mesenchymal progenitor cells. Stem Cells Dev. 2013;22(1):102-13. https://doi.org/10. 1089/scd.2012.0127.

Lach MS, Wroblewska J, Kulcenty K, Richter M, Trzeciak T, Suchorska WM. Chondrogenic Differentiation of Pluripotent Stem Cells under Controllable Serum-Free Conditions. Int J Mol Sci. 2019;20(11). https://doi.org/10 3390/ijms20112711.

Lagunas A, Comelles J, Oberhansl S, Hortigüela V, Martínez E, Samitier J. Continuous bone morphogenetic protein-2 gradients for concentration effect studies on C2C12 osteogenic fate. Nanomedicine. 2013;9(5):694701. https://doi.org/10.1016/j.nano.2012.12.002.

Lee H, Kim H, Seo J, et al. TissueGene-C promotes an anti-inflammatory micro-environment in a rat monoiodoacetate model of osteoarthritis via polarization of M2 macrophages leading to pain relief and structural improvement. Inflammopharmacology. 2020;28(5):1237-52. https://doi. org/10.1007/s10787-020-00738-y.

Lee J, Lee J, Chae B, et al. Scaffold-Free bead-type autologous chondrocyte implantation for cartilage repair - phase 1 clinical trial. Osteoarthr Cartil. 2017b;25:S175-6. https://doi.org/10.1016/j.joca.2017.02.304.

Lee J, Smeriglio P, Chu CR, Bhutani N. Human iPSC-derived chondrocytes mimic juvenile chondrocyte function for the dual advantage of 
increased proliferation and resistance to IL-1 $\beta$. Stem Cell Res Ther. 2017a;8(1):244. https://doi.org/10.1186/s13287-017-0696-x.

Lee JJ, Lee SJ, Lee TJ, Yoon TH, Choi CH. Results of microfracture in the osteoarthritic knee with focal full-thickness articular cartilage defects and concomitant medial meniscal tears. Knee Surg Relat Res. 2013;25(2):71-6. https://doi.org/10.5792/ksrr.2013.25.2.71.

Liao Y-J, Chen Y-S, Lee J-X, Chen L-R, Yang J-R. Effects of Klf4 and c-Myc Knockdown on Pluripotency Maintenance in Porcine Induced Pluripotent Stem Cell. Cell J. 2018;19(4):640-6. https://doi.org/10.22074/cellj.2018. 4428.

Liu H, Ye Z, Kim Y, Sharkis S, Jang Y-Y. Generation of endoderm-derived human induced pluripotent stem cells from primary hepatocytes. Hepatology. 2010;51(5):1810-9. https://doi.org/10.1002/hep.23626.

Liu J, Nie H, Xu Z, et al. The effect of 3D nanofibrous scaffolds on the chondrogenesis of induced pluripotent stem cells and their application in restoration of cartilage defects. PLoS One. 2014;9(11):e111566. https:// doi.org/10.1371/journal.pone.0111566.

Liu X, Shi S, Feng Q, et al. Surface Chemical Gradient Affects the Differentiation of Human Adipose-Derived Stem Cells via ERK1/2 Signaling Pathway. ACS Appl Mater Interfaces. 2015;7(33):18473-82. https://doi.org/10. 1021/acsami.5b04635.

Lu T-J, Chiu F-Y, Chiu H-Y, Chang M-C, Hung S-C. Chondrogenic Differentiation of Mesenchymal Stem Cells in Three-Dimensional Chitosan Film Culture. Cell Transplant. 2017;26(3):417-27. https://doi.org/10.3727/ $096368916 \times 693464$

Lundgren A, Hulander M, Brorsson J, et al. Gold-Nanoparticle-Assisted SelfAssembly of Chemical Gradients with Tunable Sub- $50 \mathrm{~nm}$ Molecular Domains. Part Part Syst Charact. 2014;31(2):209-18. https://doi.org/10. 1002/ppsc.201300154

Mahadik BP, Wheeler TD, Skertich LJ, Kenis PJA, Harley BAC. Microfluidic generation of gradient hydrogels to modulate hematopoietic stem cell culture environment. Adv Healthc Mater. 2014;3(3):449-58. https://doi. org/10.1002/adhm.201300263.

Maleki M, Ghanbarvand F, Behvarz MR, Ejtemaei M, Ghadirkhomi E. Comparison of Mesenchymal Stem Cell Markers in Multiple Human Adult Stem Cells. Int J Stem Cells. 2014;7(2):118-26. https://doi.org/10.15283/ijsc. 2014.7.2.118.

Meng F, Zhang Z, Huang G, et al. Chondrogenesis of mesenchymal stem cells in a novel hyaluronate-collagen-tricalcium phosphate scaffolds for knee repair. Eur Cells Mater. 2016;31:79-94. https://doi.org/10.22203/ eCM.v031a06

Miller DM, Thomas SD, Islam A, Muench D, Sedoris K. c-Myc and cancer metabolism. Clin Cancer Res. 2012;18(20):5546-53. https://doi.org/10. 1158/1078-0432.CCR-12-0977.

Miller ED, Li K, Kanade T, Weiss LE, Walker LM, Campbell PG. Spatially directed guidance of stem cell population migration by immobilized patterns of growth factors. Biomaterials. 2011;32(11):2775-85. https://doi.org/10. 1016/j.biomaterials.2010.12.005

Mina C, Garrett WE, Pietrobon R, Glisson R, Higgins L. High Tibial Osteotomy for Unloading Osteochondral Defects in the Medial Compartment of the Knee. Am J Sports Med. 2008;36(5):949-55. https://doi.org/10.1177/ 0363546508315471

Minchiotti G, Parisi S, Persico MG. Cripto signaling in differentiating embryonic stem cells. Methods Mol Biol. 2006;329:151-69. https://doi.org/10. 1385/1-59745-037-5:151.

Ministry of Food and Drug safety [Internet]. Biological Products (Cell therapy products) Medipost. Published 2016. Accessed September 16, 2021. https://www.mfds.go.kr/eng/brd/m_30/view.do?seq=69798\&srchFr=

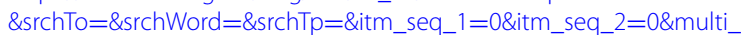
itm_seq $=0 \&$ company_cd=\&company_nm $=\& p a g e=1$

Ministry of Food and Drug Safety [Internet]. Drug Approval Report. Published 2019. Accessed September 16, 2021. https://www.mfds.go.kr/docvi ewer/skin/doc.html?fn=20200731093037314.pdf\&rs=/docviewer/ result/eng0004/70435/1/202109

Ministry of Health, Labour and Welfare [Internet]. Report on the Deliberation Results. Published 2012. Accessed September 16, 2021. https://www. pmda.go.jp/files/000229937.pdf

Möller T, Amoroso M, Hägg D, et al. In Vivo Chondrogenesis in 3D Bioprinted Human Cell-laden Hydrogel Constructs. Plast Reconstr surgery Glob open. 2017;5(2):e1227. https://doi.org/10.1097/GOX.0000000000 001227.
Mormone E, D'Sousa S, Alexeeva V, Bederson MM, Germano IM. "FootprintFree" Human Induced Pluripotent Stem Cell-Derived Astrocytes for In Vivo Cell-Based Therapy. Stem Cells Dev. 2014;23(21):2626-36. https://doi.org/10.1089/scd.2014.0151.

Nah H-D, Swoboda B, Birk DE, Kirsch T. Type IIA procollagen: Expression in developing chicken limb cartilage and human osteoarthritic articular cartilage. Dev Dyn. 2001;220(4):307-22. https://doi.org/10.1002/dvdy. 1109.

Nakagawa M, Takizawa N, Narita M, Ichisaka T, Yamanaka S. Promotion of direct reprogramming by transformation-deficient Myc. Proc Natl Acad Sci. 2010;107(32):14152-7. https://doi.org/10.1073/pnas.10093 74107.

Nakayama N, Ravuri S, Huard J. Rejuvenated Stem/Progenitor Cells for Cartilage Repair Using the Pluripotent Stem Cell Technology. Bioengineering. 2021;8(4):46. https://doi.org/10.3390/bioengineering8040046.

Naranda J, Gradišnik L, Gorenjak M, Vogrin M, Maver U. Isolation and characterization of human articular chondrocytes from surgical waste after total knee arthroplasty (TKA). PeerJ. 2017;5:e3079. https://doi.org/10. 7717/peerj.3079.

Nejadnik H, Diecke S, Lenkov OD, et al. Improved approach for chondrogenic differentiation of human induced pluripotent stem cells. Stem cell Rev reports. 2015;11(2):242-53. https://doi.org/10.1007/ s12015-014-9581-5.

Nguyen D, Hägg DA, Forsman A, et al. Cartilage Tissue Engineering by the 3D Bioprinting of iPS Cells in a Nanocellulose/Alginate Bioink. Sci Rep. 2017;7(1):658. https://doi.org/10.1038/s41598-017-00690-y.

Nguyen LH, Kudva AK, Saxena NS, Roy K. Engineering articular cartilage with spatially-varying matrix composition and mechanical properties from a single stem cell population using a multi-layered hydrogel. Biomaterials. 2011;32(29):6946-52. https://doi.org/10.1016/j.biomaterials.2011. 06.014.

O'Grady B, Balikov DA, Wang JX, et al. Spatiotemporal control and modeling of morphogen delivery to induce gradient patterning of stem cell differentiation using fluidic channels. Biomater Sci. 2019;7(4):1358-71. https://doi.org/10.1039/c8bm01199k.

Ogura T, Mosier BA, Bryant T, Minas T. A 20-Year Follow-up After First-Generation Autologous Chondrocyte Implantation. Am J Sports Med. 2017:45(12):2751-61. https://doi.org/10.1177/0363546517716631.

Oh SH, An DB, Kim TH, Lee JH. Wide-range stiffness gradient PVA/HA hydrogel to investigate stem cell differentiation behavior. Acta Biomater. 2016;35:23-31. https://doi.org/10.1016/j.actbio.2016.02.016.

Okita K, Ichisaka T, Yamanaka S. Generation of germline-competent induced pluripotent stem cells. Nature. 2007;448(7151):313-7. https://doi.org/ 10.1038/nature05934

Okita K, Nakagawa M, Hyenjong H, Ichisaka T, Yamanaka S. Generation of Mouse Induced Pluripotent Stem Cells Without Viral Vectors. Science (80- ). 2008;322(5903):949-53. https://doi.org/10.1126/science.1164270.

Oldershaw RA, Baxter MA, Lowe ET, et al. Directed differentiation of human embryonic stem cells toward chondrocytes. Nat Biotechnol. 2010;28(11):1187-94. https://doi.org/10.1038/nbt.1683.

Park Y-B, Ha C-W, Lee C-H, Yoon YC, Park Y-G. Cartilage Regeneration in Osteoarthritic Patients by a Composite of Allogeneic Umbilical Cord BloodDerived Mesenchymal Stem Cells and Hyaluronate Hydrogel: Results from a Clinical Trial for Safety and Proof-of-Concept with 7 Years of Extended Follow-Up. Stem Cells TransI Med. 2017;6(2):613-21. https:// doi.org/10.5966/sctm.2016-0157.

Paul Ehrlich Institut German Federal Ministry of Health [Internet]. Tissue Engineered Products. Published 2014. Accessed September 16, 2021. https://www.pei.de/EN/medicinal-products/atmp/tissue-engineeredproducts/tissue-engineered-products-node

Peret BJ, Murphy WL. Controllable Soluble Protein Concentration Gradients in Hydrogel Networks. Adv Funct Mater. 2008;18(21):3410-7. https://doi. org/10.1002/adfm.200800218.

Peterson L, Vasiliadis HS, Brittberg M, Lindahl A. Autologous chondrocyte implantation: a long-term follow-up. Am J Sports Med. 2010:38(6):1117-24. https://doi.org/10.1177/0363546509357915.

Pittenger MF, Mackay AM, Beck SC, et al. Multilineage potential of adult human mesenchymal stem cells. Science. 1999;284(5411):143-7. https://doi. org/10.1126/science.284.5411.143.

Internet]. Registration number ACTRN12617001095358, A Phase I, randomised, double blind, placebo-controlled, single ascending dose study to 
evaluate the safety and tolerability of allogeneic adipose-derived mesenchymal stem cells injected into patients wi. Published 2018. Accessed March 15, 2021. http://www.anzctr.org.au/Trial/Registration/ TrialReview.aspx?id=373231

Reisman M, Adams KT. Stem cell therapy: a look at current research, regulations, and remaining hurdles. PT. 2014;39(12):846-57 http://www.ncbi. nlm.nih.gov/pubmed/25516694.

Rim YA, Nam Y, Park N, et al. Different Chondrogenic Potential among Human Induced Pluripotent Stem Cells from Diverse Origin Primary Cells. Stem Cells Int. 2018;2018:9432616. https://doi.org/10.1155/2018/9432616.

Saris DBF, Vanlauwe J, Victor J, et al. Characterized Chondrocyte Implantation Results in Better Structural Repair when Treating Symptomatic Cartilage Defects of the Knee in a Randomized Controlled Trial versus Microfracture. Am J Sports Med. 2008;36(2):235-46. https://doi.org/10.1177/ 0363546507311095 .

Schmutzer M, Aszodi A. Cell compaction influences the regenerative potential of passaged bovine articular chondrocytes in an ex vivo cartilage defect model. J Biosci Bioeng. 2017;123(4):512-22. https://doi.org/10. 1016/j.jbiosc.2016.11.002.

Shi X, Zhou J, Zhao Y, Li L, Wu H. Gradient-Regulated Hydrogel for Interface Tissue Engineering: Steering Simultaneous Osteo/Chondrogenesis of Stem Cells on a Chip. Adv Healthc Mater. 2013;2(6):846-53. https://doi. org/10.1002/adhm.201200333.

Stynarski K, de Jong WC, Snow M, Hendriks JAA, Wilson CE, Verdonk P. SingleStage Autologous Chondrocyte-Based Treatment for the Repair of Knee Cartilage Lesions: Two-Year Follow-up of a Prospective Single-Arm Multicenter Study. Am J Sports Med. 2020;48(6):1327-37. https://doi. org/10.1177/0363546520912444.

Smith Callahan LA, Policastro GM, Bernard SL, Childers EP, Boettcher R, Becker ML. Influence of discrete and continuous culture conditions on human mesenchymal stem cell lineage choice in RGD concentration gradient hydrogels. Biomacromolecules. 2013;14(9):3047-54. https://doi.org/10. 1021/bm4006112.

Song $\mathrm{R}-\mathrm{H}$, Tortorella MD, Malfait A-M, et al. Aggrecan degradation in human articular cartilage explants is mediated by both ADAMTS- 4 and ADAMTS-5. Arthritis Rheum. 2007;56(2):575-85. https://doi.org/10 1002/art.22334.

Sophia Fox AJ, Bedi A, Rodeo SA. The basic science of articular cartilage: structure, composition, and function. Sports Health. 2009;1 (6):461-8. https:// doi.org/10.1177/1941738109350438.

Suchorska WM, Augustyniak E, Richter M, Trzeciak T. Comparison of Four Protocols to Generate Chondrocyte-Like Cells from Human Induced Pluripotent Stem Cells (hiPSCs). Stem cell Rev reports. 2017a;13(2):299308. https://doi.org/10.1007/s12015-016-9708-y.

Suchorska WM, Augustyniak E, Richter M, Trzeciak T. Gene expression profile in human induced pluripotent stem cells: Chondrogenic differentiation in vitro, part A. Mol Med Rep. 2017b;15(5):2387-401. https://doi.org/10. 3892/mmr.2017.6334.

Swissmedic Swiss Agency for Therapeutic Products. Novocart 3D ${ }^{\circledR}$, (Transplantatprodukt, Humane artikuläre Chondrozyten). Published 2014. Accessed September 16, 2021. https://www.swissmedic.ch/swiss medic/en/home/humanarzneimittel/authorisations/new-medicines/ novocart-3d\%2D\%2D\%2D\%2Dtransplantatprodukt\%2D\%2Dhumaneartikulaere-chondrozy.html

Szwedowski D, Dallo I, Irlandini E, Gobbi A. Osteo-core Plasty: A Minimally Invasive Approach for Subchondral Bone Marrow Lesions of the Knee. Arthrosc Tech. 2020;9(11):e1773-7. https://doi.org/10.1016/j.eats.2020. 07.023.

Takahashi K, Tanabe K, Ohnuki M, et al. Induction of Pluripotent Stem Cells from Adult Human Fibroblasts by Defined Factors. Cell. 2007;131(5):861-72. https://doi.org/10.1016/j.cell.2007.11.019.

Takahashi K, Yamanaka S. Induction of pluripotent stem cells from mouse embryonic and adult fibroblast cultures by defined factors. Cell. 2006;126(4):663-76. https://doi.org/10.1016/j.cell.2006.07.024.

Tallheden T, Karlsson C, Brunner A, et al. Gene expression during redifferentiation of human articular chondrocytes. Osteoarthr Cartil. 2004;12(7):52535. https://doi.org/10.1016/j.joca.2004.03.004.

Teleman AA, Cohen SM. Dpp gradient formation in the Drosophila wing imaginal disc. Cell. 2000;103(6):971-80. https://doi.org/10.1016/s00928674(00)00199-9.
Tognana E, Borrione A, De Luca C, Pavesio A. Hyalograft ${ }^{\circledR}$ C: HyaluronanBased Scaffolds in Tissue-Engineered Cartilage. Cells Tissues Organs. 2007;186(2):97-103. https://doi.org/10.1159/000102539.

Wang P-Y, Clements LR, Thissen H, Tsai W-B, Voelcker NH. Screening rat mesenchymal stem cell attachment and differentiation on surface chemistries using plasma polymer gradients. Acta Biomater. 2015;11:58-67. https:// doi.org/10.1016/j.actbio.2014.09.027.

Wang T, Nimkingratana P, Smith CA, Cheng A, Hardingham TE, Kimber SJ. Enhanced chondrogenesis from human embryonic stem cells. Stem Cell Res. 2019;39:101497. https://doi.org/10.1016/j.scr.2019.101497.

Watt FM. Effect of seeding density on stability of the differentiated phenotype of pig articular chondrocytes in culture. J Cell Sci. 1988;89(Pt 3):373-8 http://www.ncbi.nlm.nih.gov/pubmed/3058725.

Wei Y, Zeng W, Wan R, et al. Chondrogenic differentiation of induced pluripotent stem cells from osteoarthritic chondrocytes in alginate matrix. Eur Cell Mater. 2012;23:1-12. https://doi.org/10.22203/ecm.v023a01.

Weissenberger M, Weissenberger MH, Gilbert F, Groll J, Evans CH, Steinert AF. Reduced hypertrophy in vitro after chondrogenic differentiation of adult human mesenchymal stem cells following adenoviral SOX9 gene delivery. BMC Musculoskelet Disord. 2020;21(1):109. https://doi.org/10. 1186/s12891-020-3137-4.

Wiggers TG, Winters M, Van den Boom NA, Haisma HJ, Moen MH. Autologous stem cell therapy in knee osteoarthritis: a systematic review of randomised controlled trials. Br J Sports Med. Published online May 26, 2021:bjsports-2020-103671. doi:https://doi.org/10.1136/bjspo rts-2020-103671

Won Y-W, Patel AN, Bull DA. Cell surface engineering to enhance mesenchymal stem cell migration toward an SDF-1 gradient. Biomaterials. 2014;35(21):5627-35. https://doi.org/10.1016/j.biomaterials.2014.03. 070.

Wu Y, Kennedy P, Bonazza N, Yu Y, Dhawan A, Ozbolat I. Three-Dimensional Bioprinting of Articular Cartilage: A Systematic Review. Cartilage. 2021;12(1):76-92. https://doi.org/10.1177/1947603518809410.

Zecca M, Basler K, Struhl G. Direct and long-range action of a wingless morphogen gradient. Cell. 1996;87(5):833-44. https://doi.org/10.1016/ s0092-8674(00)81991-1.

Zhang C, Zhao X, Ao Y, Cao J, Yang L, Duan X. Proliferation ability of particulated juvenile allograft cartilage. J Orthop Surg Res. 2021;16(1):56. https://doi.org/10.1186/s13018-020-02199-z.

Zhang W, Ouyang H, Dass CR, Xu J. Current research on pharmacologic and regenerative therapies for osteoarthritis. Bone Res. 2016;4:15040. https://doi.org/10.1038/boneres.2015.40.

Zhang Z, McCaffery JM, Spencer RGS, Francomano CA. Hyaline cartilage engineered by chondrocytes in pellet culture: histological, immunohistochemical and ultrastructural analysis in comparison with cartilage explants. J Anat. 2004;205(3):229-37. https://doi.org/10.1111/j.00218782.2004.00327.x.

\section{Submit your manuscript to a SpringerOpen ${ }^{\odot}$ journal and benefit from:}

- Convenient online submission

- Rigorous peer review

- Open access: articles freely available online

- High visibility within the field

- Retaining the copyright to your article

Submit your next manuscript at springeropen.com 